\title{
The importance of legume genetic resources for breeding
}

\author{
Jegor Miladinović · Vojislav Mihailović · Vuk Đorđević · Sanja Vasiljević · \\ Snežana Katanski* · Dalibor Živanov · Predrag Ranđelović
}

Institute of Field and Vegetable Crops, Novi Sad, Republic of Serbia

\begin{abstract}
Summary: This paper presents the plant genetic resources maintained by the Center of Excellence for Legumes of the Institute of Field and Vegetable Crops, National Institute of the Republic of Serbia. The genetic resources of legumes (soybean, alfalfa, red clover, pea and vetch) are an invaluable source material and a rich source of genetic divergence for the development of varieties adapted to specific agricultural and environmental conditions. Soybean is the most important of all cultivated legumes and occupies the largest area under cultivation. The alfalfa collection consists of over 800 genotypes with different agronomic traits and dormancy values. The novel alfalfa breeding concept breeding for yield per se, based on natural heterosis in the development of half hybrids - was introduced in the late 20th and early 21 st centuries. The Center of Excellence for Legumes has 757 soybean genotypes, 655 red clover genotypes, about 730 pea genotypes and 495 vetch genotypes. The development of the winter pea variety for grain (NS Mraz), the first of its kind in South-Eastern Europe, was significant for science.

Keywords: breeding, center of excellence, genetic divergence, legumes, resources
\end{abstract}

\section{Introduction}

The Center of Excellence for Legumes of the Institute of Field and Vegetable Crops, National Institute of the Republic of Serbia in Novi Sad, was accredited in 2019. The Center includes numerous annual and perennial legumes, mainly soybean as the most important legume, forage crops (alfalfa, red clover, peas and vetches - winter and spring varieties), as well as some less commonly grown but no less important legumes (field beans, lupin, vigna, forage peas, etc.). The cultivation of legumes has become indispensable in modern livestock production, as legumes are used either as bulk or concentrate feed, green matter, hay, silage, alfalfa seed meal or feed bricks, soybean meal, soybean whey, cakes and many other products as important protein supplements (Mihailović et al., 2005a). Some of the above plant species are used for human

Corresponding author:

snezana.katanski@ifvcns.ns.ac.rs

Cite this article:

Miladinović J., Mihailović V., Đorđević V., Vasiljević S., Katanski S., Živanov D. Ranđelović P. (2021). The importance of legume genetic resources for breeding. Ratar: Pourt., 58 (3), 94-103.

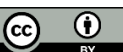

Copyright (C) The Author(s) 2021 consumption as various foods and dietary supplements. The key importance of legumes lies in their positive effect on soil structure and fertility. This is because nodules are formed at the root of legumes, which contain nitrogen-fixing bacteria and leave a nitrogen residue of $80-120 \mathrm{~kg} / \mathrm{ha}$ in the soil after the legumes have grown.

The areas under legumes in the Republic of Serbia exceed 500,000 ha. This simplifies the calculation of nitrogen residues deposited annually in Serbian soils, which exceed 50,000 tons. Legumes are considered „underground factories“ of organic nitrogen, or ,green nitrogen" as agricultural producers often say. The European Union (EU) offers considerable subsidies to legume producers because of the many benefits of legume cultivation, mainly because they reduce air, soil and water pollution, thus making an important contribution to environmental protection.

Legume genetic resources are a source of starting material and genetic diversity used to develop varieties adapted to conditions of increasing climate change, tolerant to abiotic stresses, major diseases and pests, and with improved grain and forage quality. International and national laws and regulations govern the conservation of genetic resources. Since its establishment 83 years ago, the Institute of Field and Vegetable Crops has maintained a collection of legume genotypes acquired worldwide and of local populations. 
The collection of Center of Excellence holds more than 3000 accessions of varieties and wild species as well as important breeding lines (757 soybean, 800 alfalfa, 655 red clover, 730 pea, and 495 vetch). Genetic variability expanded and increased by plant selection.

The importance of legumes is increasing due to product diversification, agricultural sustainability, and expansion of organic farming, a global trend that is particularly evident in developed countries.

\section{Significance of genetic plant resources}

Serbia has a high genetic diversity of legumes, a few of which are grown for commercial purposes, while others grow as wild populations. Evaluation and description of the collected legumes is carried out by the institutes and R\&D centres in Serbia. Of the 11,000 plant species in Europe, the flora of Serbia includes about 4,300 species (Stevanović and Vasić, 1995). The main forage plant varieties were developed by single or mass selection from native populations. Only later hybridization, modelling of ideotypes and application of modern breeding methods started.

International research centers, organizations, and countries officially joined together in 1971 to form the Consultative Group on International Agricultural Research on Resources (CGIAR) under the supervision of the World Bank. Collaboration with the Food and Agriculture Organization (FAO) led to the establishment of the International Board for Plant Genetic Resources (IBPGR) in 1974. Today, more than 1,300 institutions are registered worldwide for collecting, describing and storing plant genetic resources (Weise et al., 2017). Each breeding institution maintains a collection of developed and domesticated varieties and populations of local or international origin that are used by breeders as source material for hybridization and recombination of genes responsible for the expression of individual traits. One of the main objectives of the conservation of plant genetic resources (PGR) is to maintain genetic diversity for current and future use.

\section{Breeding and maintenance of soybean plant genetic resources}

Soybean (Glycine max L. Merr) is one of the most important crops in the world. The soybean growing area, which is more than 125 million hectares, is exceeded only by crops used extensively in the human diet - wheat, rice and maize (Hrustić et al., 1999). The soybean growing area has expanded in Serbia since the mid-1970s, after introducing the highest-quality American cultivars suitable for Serbian climate conditions and after the start of intensive soybean breeding programs at the Institute of Field and Vegetable Crops in Novi Sad. The main task of the newly-established Soybean Department was to develop high-quality, more profitable soybean cultivars better adapted to the local growing conditions. The first soybean cultivars showing agronomic properties of their predecessors were introduced to commerce in the mid1980s. Cultivars released during the 1990s (the first generation of NS soybean genetics) outrivalled foreign cultivars and occupied the entire Serbian growing area. Current soybean production in Serbia is based on the third generation of NS soybeancultivars (Apolo, Maximus, Rubin), to an extent on other domestic and foreign cultivars, as well as high-quality cultivars from breeding programs of the leading agricultural production companies. Soybean breeding programs conducted at the Center of Excellence for Legumes of the Institute of Field and Vegetable Crops resulted in 159 cultivars being released in Serbia and 192 cultivars abroad.

Since soybean is a self-pollinating plant with a low percentage of open pollination, initial soybean breeding variability can be obtained by crossing different genotypes. The choice of parental pairs for crossing, generally a complex process, becomes particularly difficult in soybean breeding due to a highly narrow gene pool (Miladinović et al., 1999). Over $80 \%$ of the soybean gene pool consists of modern American cultivars, developed using only ten genotypes from China introduced in the early 1900s. Modern soybean breeding began in the USA during the 1920s, and novel cultivars spread to South America, Europe, India, and even to China's centre of soybean origin. Their introduction, hybridization and selection were conducted in soybean breeding programs around the world. Investigating the origin of 256 North American cultivars developed between 1947 and 1988, Gizlice et al. (1994) found that only 13 ancestral genotypes make up $80 \%$ of the American soybean cultivar gene pool.

Notably, the in-depth analyses of American soybean cultivars confirmed that 35 ancestral genotypes comprise over $95 \%$ of the soybean gene pool. A considerably shorter list of ancestral genotypes of NS cultivars is revealed since the commonly grown NS cultivars (Afrodita, Balkan, Vojvođanka) were developed from the widespread American cultivars (Hodgson, Evans, S1347) and that the parental component coefficient of Hodgson and Corsoy and Evans and Corsoy were 0.566 and 0.484, respectively (Allen and Bhardwaj, 1987). Analysis of parental components without in-depth analysis and determination of origin resulted in 60 different genotypes, 18 of which comprise about $70 \%$ of the gene pool, while 42 comprise less than 1\% (Miladinović et al., 2008). Recent research has shown that the gene pool of NS soybean varieties consists of 137 genotypes, of which 24 genotypes comprise nearly $60 \%$, while the remaining ones represent less than $1 \%$ (unpublished data).

It is not easy for a soybean breeder to select the starting material for breeding from numerous genotypes with a similar genetic origin because only crossing genetically divergent genotypes results in transgressive separation for economically important traits. 
Germplasm collections are essential for cultivar development and improvement and, as the source of parental components, key for the variability of the desired traits.

The collection is updated regularly, mainly by ordering samples from other germplasm collections (recently from one of the largest, the USDA Soybean Germplasm Collection at the University of Illinois, Urbana, IL, USA, consisting of over 22,000 genotypes), by participating in projects that test genetic material, such as international project EUCLEG - Breeding forage and grain legumes to increase Eu's and China's protein self-sufficiency, which screened a total of 360 soybean cultivars, and ECOBREED - Increasing the efficiency and competitiveness of organic crop breeding, which will analyze 206 soybean cultivars developed under different European agroecological conditions. Within the framework of bilateral cooperation based on MTAs (Material Transfer Agreements), trials were carried out to test genotypes from the companies Euralis (France), Agroscope (Switzerland), Danube Soya Association (Austria).

The Institute maintains 757 soybean (Glycine $\max (\mathrm{L}$.$) Merr) genotypes from the USA, Asia and$ Europe. Several hundreds of samples donated to the VIR (N.I. Vavilov Research Institute) gene bank are available for review at http://vir.nw.ru.

The soybean collection is maintained by sowing every year or every other year to maintain seed germination. Observations are made during the growing season according to the internal descriptor for soybean, which meets the requirements of breeding programs and is more detailed than the UPOV (International Union for the Protection of New Varieties of Plants) International Guidelines for the Conduct of DUS (Distinctness, Uniformity and Stability) Tests (1998). The results are recorded and entered into the Microsoft Excel database. Harvesting is done manually or mechanically using a combined harvester for microtests. The obtained seed samples are analyzed and evaluated according to the internal soybean descriptors. The seed is stored and maintained under predefined storage conditions.

\section{Genetic resources of alfalfa, red clover, peas and vetch (winter and spring cultivars)}

Alfalfa (Medicago sativa L.) is a perennial forage crop with a high genetic potential for a yield of bulk fodder and, as such, an essential component of sustainable forage production worldwide ( $\mathrm{Li}$ and Brummer, 2012). The end of World War II marked the beginning of alfalfa breeding in Serbia, initially conducted using simple breeding methods, local (autochthonous) populations, and mass selection as the oldest method of breeding new cultivars (Mihailović et al., 2008). Alfalfa breeding programs, conducted in Novi
Sad using mass and individual selection, which differ in their breeding goals and methods, resulted in the development of many alfalfa cultivars and populations intended for different regions of cultivation in Serbia and abroad (Mihailović et al., 2008; Milić et al., 2019). Research on the efficiency of progeny tests in alfalfa breeding using different methods (self-pollination, open pollination, and diallel crossing) is also conducted at the Center of Excellence for Legumes, resulting in the development of experimental alfalfa populations with different dormancy scores (Milić et al., 2019).

The Department of Forage Crops has conducted alfalfa breeding for more than five decades, which resulted in the development of 18 alfalfa cultivars inscribed in Serbia, as well as nine cultivars released abroad (EU, Belarus, Ukraine, Morocco, and Turkey). Alfalfa breeding was conducted in several cycles (Mihailović et al., 2008). The first breeding cycle, characterized by the inclusion of local indigenous populations and conducted through mass and individual selection, resulted in NS Banat ZMS II, NS Bačka ZMS I and NS Vršac ZMS IV. The second cycle of alfalfa breeding included the application of interspecific crossing (M. sativa $\mathrm{x} M$. falcata) as a method of cultivar development. It marked the beginning of the development of synthetic cultivars and the second generation of alfalfa cultivars (NS Mediana ZMS V, Novosađanka X-11). The third breeding cycle (the early 1990s) was marked by developing synthetic alfalfa varieties with a broad gene pool, increasing resistance to the dominant alfalfa diseases in Serbia. Most cultivars were developed during this period (Slavija, Rasinka, Tisa, Begej, and the latest Banat VS, NS Alfa, Nijagara, Nera and NS Media).

Moreover, the distinction between the cycles and the applied breeding methods is broad due to the intertwining of breeding methods across the specific cycles. For example, Danka (2003) and Nijagara (2007) developed in the third cycle using domestic and foreign germplasm containing blue and yellow alfalfa types. Alfalfa cultivars developed in the previous breeding cycles are characterized by exceptionally high forage and hay yields. NS Banat ZMS II is an early, adaptable, drought-resistant cultivar of excellent quality, intended for intensive cutting systems and cultivation on highquality soils. Cultivar NS Mediana ZMS V, with good production characteristics, was also developed during the previous breeding cycle at the Department of Forage Crops. The fourth cycle of alfalfa breeding at the Institute of Field and Vegetable Crops (2010-2020) was the period of introduction of new methods of semi -hybrid breeding, which led to the development of the first semi-hybrid alfalfa varieties adapted to various agro-ecological conditions and production systems in Serbia and abroad (NS Jelena, NS Sila, NS Tara).

Wide genetic variability of the material used in breeding new alfalfa varieties is of vital importance. 
Table 1. Genetic resources and alfalfa population structure at the Center of Excellence for Legumes

\begin{tabular}{cc}
\hline Medicago sativa L. ssp. complex & No. of Populations \\
\hline M. s. subsp. sativa & 749 \\
M. s. subsp. varia & 50 \\
M. s. subsp. caerulea & 1 \\
Total & $\mathbf{8 0 0}$ \\
\hline Dormancy Score & No. of Populations \\
2 & 5 \\
3 & 22 \\
$3-4$ & 150 \\
$4-5$ & 300 \\
$5-6$ & 160 \\
$6-7$ & 35 \\
8 & 5 \\
9 & 1 \\
Total & $\mathbf{8 0 0}$ \\
\hline
\end{tabular}

Since the beginning of alfalfa breeding conducted at the Institute of Field and Vegetable Crops, the goal was to expand the genetic collection of alfalfa genotypes, not only by collecting indigenous populations but also by the exchange of cultivars with the domestic and foreign research institutions (Mihailović et al., 2008). Genotypes obtained through an exchange with other institutions and gene banks have been included in breeding programs and contributed to the new alfalfa cultivar development (Table 1). Furthermore, the participation of researchers in international projects aimed to test alfalfa populations is a way to increase the genetic collection of alfalfa (Table 1). For instance, in the scope of the international project EUCLEG, 'Breeding forage and grain legumes to increase Eu's and China's protein self-sufficiency", 350 varieties and experimental populations of alfalfa from all over the world were tested in the agroecological conditions of Serbia.

As a result of the different breeding goals, alfalfa varieties developed in Novi Sad differ in their maturity time, i.e. dormancy (Mihailović et al., 2008).

From a global perspective, the end of the 20th century and the beginning of the 21 st century were marked by the application of a new concept of alfalfa breeding for yield, which exploits heterosis in the semihybrids or open-pollinated hybrids by crossing the selected heterotic populations whose progeny exhibit heterosis (Milić et al., 2011). Research results show that crossing of alfalfa cultivars leads to pronounced heterosis effects and significant increase in alfalfa yield (Milić et al., 2013). Modern breeding methods (semihybrid breeding) are one way to increase the yield of alfalfa biomass, and feed producers can expect the release of new, high-yielding and high-quality alfalfa varieties in the coming years. The basis for successful alfalfa breeding is the rich genetic collection of alfalfa genotypes at the Institute of Field and Vegetable Crops, which has been maintained for over 50 years and expanded and improved during the 50 years of research on alfalfa breeding in Novi Sad.
Red clover (Trifolium pratense L.), grown on about 90,000-120,000 ha, is the second most important perennial forage legume in the Republic of Serbia. It is grown mainly in the hilly and mountainous areas of central Serbia on acid soils and under humid climatic conditions. The Institute of Field and Vegetable Crops established the red clover collection 20 years ago to ensure wide genetic variability for red clover breeding. Originally, the collection was supplemented with red clover populations from Serbia and Republika Srpska. However, it has been considerably expanded through intensive international cooperation with the renowned plant genebanks and institutes holding genetic reference collections of red clover (Table 2).

Current global and regional goals in red clover breeding are the development of high biomass (green fodder and hay) cultivars, tolerant to biotic and abiotic stress, with satisfactory quality, higher protein content, and improved digestibility (Vasiljević et al. 1999). Red clover in sustainable production systems is increasingly more important due to its ability to fix nitrogen, prevent excessive use of mineral fertilizers and pesticides and secure environmental protection. To keep up with the trends of sustainable organic agriculture and safe fodder production, novel red clover breeding strategies aim to develop new cultivars with better quality and improved agronomic traits - higher non-degradable proteins and lower phytoestrogen content (Vasiljevic et al., 2005; Vasiljevic et al., 2009; Vasiljevic et al., 2011; Vasiljevic et al., 2019). Concurrently, there are numerous examples of alternative use of red clover in the production of functional foods rich in isoflavones (Bursac et al., 2011; Vasiljevic et al., 2013a; Vlaisavljevic et al., 2014; Vlaisavljevic et al., 2016).

Numerous national, regional and international projects invest significant resources in collecting and studying local and wild populations of red clover: COST Action 852 "Quality Legume-Based Forage Systems for Contrasting Environments" (2002-2006), "Conservation and sustainable use of genetic resources fodder plants" (2007-2008), Regional project SeedNet "Regional collecting expedition and ex-situ conservation of Trifolium pratense L. and Festuca pratensis Huds" (2007-2010), "Preservation and sustainable use of wild and cultivated legumes in Serbia and Slovakia" (2010- 2011), and EUCLEG "Breeding forage and grain legumes to increase Eu's and China's protein self-sufficiency" (2017-2021). As a result of breeding red clover at the Institute of Field and Vegetable Crops, seven red clover cultivars have been registered in Serbia (Kolubara, Una, Avala, NS-Mlava, NS-Ravanica, NS-Petnica, and NS-Sana). In comparison, five cultivars have been released abroad.

Genetic resources collection maintained at the Center of Excellence for Legumes consists of 655 samples (Table 2). Due to a lack of adequate conditions for long-term seed storage at the Center, red clover collection is used exclusively in preliminary breeding, evaluation and characterization of the key 
morphological, biological and agronomic traits conducted at the Rimski Šančevi experimental fields (Vasiljevic et al., 2006; Vasiljevic et al., 2007; Vasiljevic et al., 2012).

Characterization and evaluation of the most important red clover traits imply extensive and timeconsuming research conducted using a specific set of plants (core collection). Characterization and evaluation of samples in germplasm collections refers to the descriptors which include qualitative and quantitative traits. Qualitative descriptors include morphological, physiological and molecular (biochemical and DNA) properties, while quantitative descriptors are under the effect of environmental factors (Nikolić et al., 2010; Šurlan -Momirović et al., 2010; Ćalić et al., 2015).

The specifically selected sets of red clover genotypes kept at the Center of Excellence for Legumes were grouped into six clusters based on phenotypic characterization. The identical genotypes were grouped into 13 different clusters based on molecular characterization (using SSR molecular markers).
Cluster analysis based on phenotypes and SSR molecular markers indicates a high level of genetic diversity (Ahsyee et al., 2014; Radinovic et al., 2017). Although the previous analysis was performed using phenotypic and molecular markers to group genotypes into appropriate clusters, the Mantel test indicated the absence of coincidence in the composition of groups at the phenotypic and molecular level, which is in agreement with the existing data and results (Dias et al., 2008; Pagnotta et al., 2011; Vasiljevic et al., 2013 b).

Characterization of the selected red clover genotypes kept in the Center of Excellence for Legumes was carried out using Mantel test. A statistically significant positive correlation was observed between the distance matrix of attributive traits and agronomic traits, leading to the conclusion that genotypes with similar attributive traits share to some extent the same agronomic and chemical traits, which facilitates the selection of superior genotypes with desirable traits for future breeding of red clover (Vasiljevic et al., 2018; Radinovic et al., 2018).

Table 2. Collection of red clover (Trifolium pretense L.) in the Center of Excellence for Legumes

\begin{tabular}{|c|c|c|}
\hline Institution & Contry of Origin & No. of Samples \\
\hline Plant Research International, Vageningen & The Netherlands & $152 \mathrm{c}+43^{* *}+5^{*}$ \\
\hline IPK-Gatersleben & Germany & $148 \mathrm{c}$ \\
\hline Nordic Gene Bank & Sweden & $128 \mathrm{c}$ \\
\hline Institute of Field and Vegetable Crops, Novi Sad & Serbia & $41 *+7 \mathrm{c}$ \\
\hline Federal Centre for Breeding Research on Cultivated Plants- Braunschweig & Germany & $26 \mathrm{c}$ \\
\hline N.I. Vavilov Research Institute of Plant Industry (VIR), St. Petersburg & Russia & $15^{*}$ \\
\hline USDA/ARS Western Regional Plant Introduction Station, Washington State University & USA & $14 \mathrm{c}$ \\
\hline Institute of Plant Genetic Resources (IPGR), Sadovo & Bulgaria & $10^{* *}+1 \mathrm{c}$ \\
\hline Research Institute of Plant Production, Piešt'any & Slovakia & $10 \mathrm{c}+8^{* *}+2^{*}$ \\
\hline National Centre for Plant Genetic Resources of Ukraine (NCPGRU), Kharkiv & Ukraine & $8 \mathrm{c}$ \\
\hline Australian Medicago Genetic Resource Centre & South Australia & $6 \mathrm{c}$ \\
\hline Institute of Agriculture, Banja Luka & Republic of Srpska & $5^{*}$ \\
\hline GKI - Szeged, Hungary; OKI -Szarvas & Hungary & $4 \mathrm{c}$ \\
\hline Departement plantengenetica en Veredeling & Belgium & $3 \mathrm{c}$ \\
\hline Jogeva Plant Breeding Institute & Estonia & $3 \mathrm{c}$ \\
\hline Banca de Resurse Genetice Vegetale - Suceava & Romania & $3 \mathrm{c}$ \\
\hline Saatzucht Steinach GmbH & Germany & $3 \mathrm{c}$ \\
\hline Institute of Forage Crops, Kruševac & Serbia & $2 \mathrm{c}$ \\
\hline Universidad Mayor de san Simon, Facultad de Sciencias Agricolas & Bolivia & $2 \mathrm{c}$ \\
\hline International Center for Agricultural Research in the Dry Areas & Syria & $2 *$ \\
\hline National Agricultural Research Foundation Fodder Crops and Pastures Institute & Greece & $1 \mathrm{c}$ \\
\hline Hokkaido Agricultural Research Center & Japan & $3 \mathrm{c}$ \\
\hline Research and Practical center of the National Academy of Belarus for Arable Farming & Belarus & $3 \mathrm{c}$ \\
\hline \multicolumn{2}{|l|}{ Total } & 655 \\
\hline
\end{tabular}

Source: Characterization and utilization of red clover (Trifolium pretense L.) collection in Novi Sad (Vasiljevic et al.,2012); Legend: c - cultivar,

* - local population, ** - wild population 
Pea (Pisum ssp.) and Vetch (Vicia sativa, L., Vicia villosa Roth. and Vicia pannonica Grantz), grown on 30 to 35,000 ha as winter and spring crops, are the most widespread annual forage legumes in Serbia. They are used in the production of bulky feeds and concentrates - green forage, hay, haylage, silage and dry grain - and in sideration, i.e. green manuring (Mihailovic et al., 2005b).

The collection and breeding of winter forage peas and vetches began after the establishment of the Agricultural Experiment Station. The first varieties of winter forage pea (NS Pionir and NS Dunav) were registered as early as 1977 in the former Yugoslavia. Intensive collection of wild populations from all over the world and planned hybridization started in 1982, when detail-oriented, long-term breeding was carried out, leading to the development of the first spring forage pea genotypes. To date, a large number of different winter and spring pea genotypes have been collected. The Center of Excellence for Legumes of the Institute of Field and Vegetable Crops Novi Sad maintains one of the most complete collections of the genus Pisum ssp. with over 730 collection numbers of the genus Vicia ssp. with 495 genotypes (Mihailović et al., 2006). Research results in 40-60 genotype combinations each year using different variants of convergent and divergent crosses, with special attention paid to the selection of parent pairs for hybridization. The concept of traits is a selective development of certain traits by selecting parent pairs for crossing based on familiarity with the desired traits in a new variety.
Validation of the results contributed to the recognition of the Institute of Field and Vegetable Crops and its inclusion in a comprehensive three-yearlong international project EUCLEG (2017). One of the work packages of the project relates to field peas and grain peas. It comprises 320 genotypes from Europe and the world, including about 70 genotypes from the Centre of Excellence for Legumes. Such projects contribute, in particular, to the multiplication of germplasm and the dissemination of genetic variability, while at the same time allowing comparison between the results of the Institute's varieties and those of other research centres.

As a result of decades of research, the Institute now has 22 cultivars of winter and spring peas registered in Serbia and nine cultivars successfully grown abroad. In addition, 14 vetch cultivars have been registered in Serbia and six have been approved abroad, as well as four field bean cultivars, two lupin cultivars, two grass pea cultivars and one cultivar of bad and white mustard. Years of research and the use of successive, double and triple crosses resulted in the first two winter pea varieties in Southeast Europe (NS Mraz and NS Zlatar) with the grain yield potential above seven $t \mathrm{ha}^{-1}$, early maturity and frost-resistance (Mihailović et al. 2019).

Numerous collection expeditions and several international projects (SEEDnet, Sierra I and Sierra II) have been conducted to locate and collect wild populations of forage legumes. In 2005, the Ministry of Agriculture, Forestry and Water Management supported the project GREJMA 05 to preserve and

Table 3. Institutions with large collections of annual leguminous crops

Australian Collections of Plant Genetic Resources (ACPGR), Australia, http://www2.dpi.qld.gov.au/extra/asp/AusPGRIS

Institute for Agrobotany (ABI), Tápiószele, Hungary, http://www.rcat.hu

Institute of Plant Genetic Resources (IPGR), Sadovo, Bulgaria, http://www.genebank.hit.bg

International Centre for Agricultural Research in the Dry Areas (ICARDA), Aleppo, Syria, http://www.icarda.cgiar.org

International Center for Tropical Agriculture (CIAT), http://www.ciat.cgiar.org

International Crops Research Institute for the Semi-Arid Tropics (ICRISAT), http://www.icrisat.org

International Institute of Tropical Agriculture (IITA), http://www.iita.org

John Innes Centre (JIC), Norwich, United Kingdom, http://www.jic.ac.uk

Leibniz Institute of Plant Genetics and Crop Plant Research (IPK), Gatersleben, Germany, http://www.ipk-gatersleben.de

N.I. Vavilov Research Institute of Plant Industry (VIR), St. Petersburg, Russia, http://www.vir.nw.ru

National Institute of Agriculture and Food Research (INIA), Plant Genetic Resources Centre (CRF), Spain, http://www.inia.es

The Centre for Genetic Resources, the Netherlands (CGN), Wageningen, The Netherlands, http://www.cgn.wur.nl

The National Research Council (CNR), Institute of Plant Genetics (IGV), Bari, Italy, http://www.igv.cnr.it

The World Vegetable Center (AVRDC), http://www.avrdc.org

United States Department of Agriculture (USDA), Agricultural Research Service (ARS), National Plant Germplasm System (NPGS), United States of America, http://www.ars-grin.gov/npgs

Yurjev Plant Breeding Institute, National Centre for Plant Genetic Resources of Ukraine (NCPGRU), Kharkiv, Ukraine 
Table 4. Structure of genetic resources according to genus and species

\begin{tabular}{|c|c|c|c|}
\hline Genus & Species & English name(s) & $\begin{array}{c}\text { No. of } \\
\text { Accessions }\end{array}$ \\
\hline \multirow{2}{*}{ Arachis L. } & bypogaea L. & groundnut, peanut & 3 \\
\hline & pintoi Krapov. \& W. C. Greg. & pinto peanut & 1 \\
\hline Cajanus Adans. & cajan (L.) Millsp. & pigeon pea & 7 \\
\hline Calopogonium Desv. & mucunoides Desv. & calopo & 1 \\
\hline Cicer L. & arietinum $\mathrm{L}$. & chickpea & 58 \\
\hline Lablab Adans. & purpureus (L.) Sweet & hyacinth bean, lablab bean & 3 \\
\hline \multirow{16}{*}{ Lathyrus L. } & angulatus L. & angled pea & 1 \\
\hline & annuus $\mathrm{L}$. & annual vetchling & 1 \\
\hline & aphaca $\mathrm{L}$. & yellow vetchling & 1 \\
\hline & belinensis Maxted \& Goyder & Belin sweet pea & 1 \\
\hline & chloranthus Boiss. & lime pea & 1 \\
\hline & cicera $\mathrm{L}$. & flat-podded vetchling & 11 \\
\hline & clymenum $\mathrm{L}$. & Spanish vetchling & 2 \\
\hline & hirsutus L. & hairy vetchling & 1 \\
\hline & inconspicuus L. & inconspicuous pea & 1 \\
\hline & latifolius $\mathrm{L}$. & broad-leaved everlasting pea & 3 \\
\hline & ochrus (L.) DC. & ochrus vetch, Cyprus vetch & 2 \\
\hline & odoratus L. & sweet pea & 21 \\
\hline & pratensis L. & meadow vetchling & 2 \\
\hline & sativus $\mathrm{L}$. & grass pea, chickling pea & 32 \\
\hline & tingitanus $\mathrm{L}$. & Tangier pea & 1 \\
\hline & tuberosus $\mathrm{L}$. & groundnut peavine & 3 \\
\hline Lens Mill. & culinaris Medik. & lentil & 45 \\
\hline \multirow{10}{*}{ Lupinus L. } & albus L. & white lupin & 68 \\
\hline & angustifolius $\mathrm{L}$. & narrow-leaved lupin, blue lupin & 17 \\
\hline & bispanicus L. & Spanish lupin & 20 \\
\hline & hybr. & lupin hybrids & 1 \\
\hline & lepidus Douglas ex. Lindl. & Pacific lupin, dwarf lupin & 1 \\
\hline & luteus $\mathrm{L}$. & yellow lupin & 44 \\
\hline & mexicanus Cerv. ex Lag. & Mexican lupin & 1 \\
\hline & mutabilis Sweet & Andean lupin & 8 \\
\hline & nanus Douglas ex Benth. & sky lupin, field lupin & 3 \\
\hline & polyphyllus Lindl. & garden lupin & 1 \\
\hline Macrotyloma (Wight\&Arn.) Verdc. & axillare (E. Mey.) Verdc. & perennial horse gram & 1 \\
\hline Mucuna Adans. & pruriens (L.) DC. & Bengal bean & 1 \\
\hline \multirow{3}{*}{ Ornithopus L. } & perpusillus L. & common serradella & 1 \\
\hline & pinnatus (Mill.) Druce & slender serradella & 1 \\
\hline & sativus Brot. & French serradella & 2 \\
\hline \multirow{2}{*}{ Pisum L. } & fulvum $\mathrm{Sm}$. & tawny pea, red-yellow pea & 13 \\
\hline & sativum $\mathrm{L}$. & (common) pea & 717 \\
\hline Stylosanthes Sw. & capitata Vogel & capitata pencilflower & 1 \\
\hline Trigonella L. & foenum-graecum $\mathrm{L}$. & fenugreek & 1 \\
\hline \multirow{22}{*}{ Vicia L. } & bithynica (L.) L. & Bithynian vetch & 2 \\
\hline & cracca $\mathrm{L}$. & cow vetch, tufted vetch & 1 \\
\hline & disperma DC. & two-seed vetch & 1 \\
\hline & ervilia (L.) Willd. & bitter vetch & 4 \\
\hline & faba L. & faba bean, field bean, broad bean & 69 \\
\hline & galilaea Plitm. \& D. Zoh. in Plitm. & Galilee vetch & 1 \\
\hline & grandiflora Scop. & large-flowered vetch & 26 \\
\hline & birsuta (L.) Gray & common tare, tiny vetch & 2 \\
\hline & byaeniscyamus Mouterde & hyaena bean & 2 \\
\hline & lathyroides L. & spring vetch & 1 \\
\hline & lutea $\mathrm{L}$. & yellow vetch & 4 \\
\hline & michauxii Spreng. & Michaux vetch & 1 \\
\hline & narbonensis $\mathrm{L}$. & Narbonne vetch & 45 \\
\hline & noeana Reut. ex Boiss. & natal vetch & 11 \\
\hline & pannonica Crantz & Hungarian vetch & 4 \\
\hline & parviflora Cav. & slender vetch & 1 \\
\hline & pisiformis L. & pea vetch, pale-flowered vetch & 3 \\
\hline & sativa $\mathrm{L}$. & common vetch & 287 \\
\hline & sylvatica $\mathrm{L}$. & wood vetch & 1 \\
\hline & tetrasperma (L.) Schreb. & four-seed vetch, smooth vetch & 1 \\
\hline & vicioides (Desf.) Cout. & lentil vetch & 1 \\
\hline & villosa Roth & hairy vetch & 27 \\
\hline \multirow{4}{*}{ Vigna Savi } & angularis (Willd.) Ohwi \& H. Ohashi & adzuki bean & 7 \\
\hline & radiata (L.) R. Wilczek & mung bean, green gram & 7 \\
\hline & unguiculata (L.) Walp. & cowpea, black-eyed pea & 9 \\
\hline & & Total & 1,460 \\
\hline
\end{tabular}


sustain the collection of forage crops. Project goals of GREJMA 05 were:

- Examination of morphological properties of collection numbers;

- Determining the date of phenological stages of collection numbers;

- Examination of agronomic traits of collection numbers related to fodder;

- Examination of grain-related agronomic properties;

- Production of seeds, i.e. reproduction and maintenance of collection numbers

The database was created for each collection number used by breeders when selecting parental components for hybridization and international material exchange (Ćupina et al., 2006).

Germplasm regeneration is one of the most important processes in the management and conservation of genetic resources, using different methods depending on the plant species, seed germination and reproductive system. Plant genebank collections are divided into several segments: primary collections, active (working) collections, specially selected sets ("core collections"), duplicate collections, and gene collections. Tables 3 and 4 show the names of the institutions and gene banks of the countries with which material has been exchanged and the number of accession by plant species. Some research centers have donated genotypes of other legumes such as Cajanus Adams, Cicer L., Lathyrus L., Vigna ssp., Lupinus L., and others that have been less used because of their low economic importance. The collections of the genera Pisum and Vicia, which represent most of the donated samples, are of the greatest importance to the Center of Excellence for Legumes (Mikić et al., 2013).

\section{The future of legume genetic resources}

One of the future activities of the Center of Excellence for Legumes of the Institute of Field and Vegetable Crops will be the further expansion of the collection and development of genetic variability using modern methods of genomic and marker-assisted selection. In collaboration with leading researchers from Europe, America, China and other countries, we will study the structure and functioning of genes at the molecular level, learn more about the structure of the genome and thus facilitate the development of better varieties adapted to changing climatic conditions and market requirements.

The most important goals for the near future are to maintain and improve the storage conditions of existing and future collection holdings and to continue to increase them. At the same time, the aim is to further disseminate knowledge, collect data and further characterize and evaluate each genotype. This is especially important for junior researchers, who should become familiar with the source material and know exactly which genotype is superior thanks to its desirable traits. Successful breeders and breeding programs have developed new cultivar models called plant ideotypes. However, these models are useless unless one delves deeply into the matter, develops more than one cultivar, and carefully considers the agroecological conditions for which a cultivar is being developed (Borojevic, 1981). Diversity of source material and genetic resources and knowledge of genetics and breeding methods are necessary for breeding success and progress.

\section{Conclusion}

Plant genetic resources, soil, water and environment are the basis for the agricultural development of any country. The Center of Excellence for Legumes of the Field and Vegetable Crops Institute has extensive collection of soybean, alfalfa, red clover, pea and other grain and forage legumes genetic resources. The conservation of old varieties, local populations and wild relatives of legumes around the world is crucial as they carry genes responsible for the expression of many desirable traits in modern varieties.

\section{References}

Ahsyee S.R., Vasiljević S., Ćalič I., Zorić M., Karagić Đ., ŠurlanMomirović G. (2014). Genetic diversity in red clover (Trifolium pratense L.) using SSR markers. Genetika, 46 (3), 949-961. DOI: 10.2298/GENSR1403949a.

Allen F.L. and Bhardwaj H.L. (1987). Genetic relationships and selected pedigree diagrams of North American soybean cultivar. The University of Tennessee, Agricultural experimental station, Knoxville, Tennessee.

Borojević S. (1981). Principi i metodi oplemenjivanja biljaka. Ćirpanov, Novi Sad.

Bursać M., Atanacković M., Cvejić J., Vasiljević S. (2011). Analiza fitoestrogena crvene deteline. Medicina Danas, 10 (7-9), 259-265. Characterization of Italian emmer wheat accessions. Euphytica, 146, 29-37.

Ćupina B., Mihailović V. Erić P. Karagić Đ. Mikić A. Krstić Đ. Maja Ječmenica, Savić-Ivanov Milena (2006). GREJMA 05 - Program čuvanja i održivog korišćenja zbirke jednogodišnjih krmnih i zrnenih mahunarki. Tematski Zbornik IV Medunarodne Eko-konferencije „Zdravstveno bezbedna brana", Novi Sad, Srbija, 20-23 septembar 2006, 297-302.

Ćalić I., Vasiljević S., Šurlan-Momirović G., Ahsyee R.S., Karagić Đ. (2015). Grupisanje sorti i populacija crvene deteline na osnovu analize kvantitativnih osobina. XIII Simpozijum o krmnom bilju Srbije "Stanje i perspektive proizvodnje krmnog bilja u Republici Srbiji", Novi Sad, 21-22.

Dias P.M.B., Julier B., Sampoux J.P., Barre P., Dall'Agnol M. (2008). Genetic diversity in red clover (Trifolium pratense L.) revealed by morphological and microsatellites (SSR) markers. Euphytica, 160 (2), 189-205.

FAOSTAT (2006). Agricultural Data. FAO Statistical Databases (FAOSTAT), Food and Agriculture Organization of the United Nations (FAO). Available from: http:// faostat.fao.org

Gizlice Z., Carter J., Burton J. (1994). Genetic base for North American public soybean cultivars released between 1947 and 1988. Crop Science, 34, 1143-1151.

GRIN (2006). GRIN Taxonomy for Plants. United States Department of Agriculture (USDA), Agricultural Research Service (ARS), National Genetic Resources Program (NGRP), Germplasm Resources Information Network (GRIN), National Germplasm Resources Laboratory, Beltsville, Maryland, USA. Available from: http:// www.ars-grin.gov/npgs/searchgrin.html 
Hrustić M., Vidić M., Miladinović J., Tatić M. (1999). Pravci u selekciji i proizvodnji soje. Zbornik radova Instituta za ratarstvo $i$ povrtarstvo Novi Sad, 31, 335-340.

Li X. and Brummer E.C. (2012). Applied genetics and genomics in alfalfa breeding. Agronomy, 2, 40-61.

Maxted N. (1995). An Ecogeographical Study of Vicia Subgenus Vicia. International Plant Genetic Resources Institute (IPGRI), Rome, Italy, 184.

Mihailović V., Mikić A., Ćupina B., Erić P. (2005a). Field pea and vetches in Serbia and Montenegro. Grain Legumes, 44, 25-26.

Mihailović V., Mikić A., Karagić Đ., Katić S., Pataki I. (2005b). Genetic variability of yield and its components in winter forage pea cultivars. Offered Papers of the XX International Grassland Congress Grasslands - a Global Resource, Dublin, Ireland, 26 June - 1 July 2005, 90.

Mihailović V., Mikić A., Vasiljević S., Ćupina B., Krstić Đ., Milić D., Katić S., Vasić M. (2006). A collection of annual legumes at its beginnings. Proceedings of the II International Symposium of Ecologists of tha Republic of Montenegro, Kotor, Montenegro, 20-24 Septembar 2006, 449-454.

Mihailović V., Katić S., Ćupina B., Vasiljević S., Karagić Đ., Pataki I., Mikić A., Milić D. (2008). Rezultati u oplemenjivanju, agrotehnici i semenarstvu krmnih biljaka u Institutu za ratarstvo i povrtarstvo. Zbornik radova, 45, 81-101.

Mihailovic V. Vasiljevic S. Karagić Đ. Miloševic B. Milić D. Katanski S. Živanov D. Ćupina B. Krstić Đ. Popović V. (2019). Doprinos oplemenjivanja jednogodišnjih mahunarki većoj proizvodnji bilinih proteina. Zbornik sinopsisa sa XIV Simpozijuma o krmnom bilju. Poljoprivredni fakultet Beograd, Srbija, 18-19.04.2019., 1114.

Mikić A., Mihailović V., Dimitrijević M., Petrović S., Ćupina B., Đorđević V., Kosev V., Milošević B., Jovanović Ž., Milovac Ž. (2013). Evaluation of seed yield and seed yield components in red-yellow (Pisum fulvum) and Ethiopian (Pisum abyssinicum) peas. Genetic Resources and Crop Evolution, 60, 629-638.

Miladinović J., Hrustić M., Verešbaranji I. (1999). Morphological and Biochemical Linkage of Some Soybean Cultivars. World Soybean Research Conference V1, Proceedings, Chicago, USA, 04-07.08.1999., 521.

Miladinovic J., Hrustic M., Vidic M., Djordjevic V., Balesevic-Tubic S. (2008). Work on soybean breeding at the Institute of Field and Vegetable Crops in Novi Sad. Conventional and molecular breeding of field and vegetable crops, Novi Sad 24-27 November 2008. Conference proceedings, 464-467.

Milić D., Katić S., Karagić Đ., Gvozdanović-Varga J., Petrović S., Boćanski J. (2011). Genetic control of agronomic traits in alfalfa ( $M$. sativa ssp. sativa L.). Euphytica, 182 (1), 25-33. DOI 10.1007/s10681011-0434-x.

Milić D., Taški-Ajduković K., Nagl N., Katanski S., Katić S. (2013). Heterosis in alfalfa breeding. Rat. Povrt. / Field Veg. Crop Res. 50, 60-64. doi:10.5937/ratpov50-5059.

Milić D., Katanski S., Milošević B., and Živanov D. (2019). Variety selection in intensive alfalfa cutting management. Rat. Povrt. Field Veg. Crop Res., 56 (1), 20-25. doi: 10.5937/ratpov56-20528.

Nikolić Z., Vasiljević S., Karagić D., Vujaković M., Jovičić D., Katić S., Surlan-Momirović G. (2010). Genetic diversity of red clover cultivars (Trifolium pratense L.) based on protein polimorphism. Genetika, 42 (2), 249-258.

Pagnotta M.A., Annicchiarico P., Farina A., Proietti S. (2011). Characterizing the molecular and morphophysiological diversity of Italian red clover. Euphytica, 179 (3), 393-404.

Radinovic I., Vasiljevic S., Brankovic G., Ramadan Salem-Ahsyee, Momirovic U., Perovic D., Surlan-Momirovic G. (2017) Molecular characterization of red clover genotypes utilizing microsatellite markers. Chilean J. Agric. Res., 77 (1), 41-47. http:// dx.doi.org/10.4067/S0718-58392017000100005

Radinovic I., Vasiljevic S., Zoric M., Brankovic G., Živanovic T., Prodanovic S. (2018). Variability of red clover genotypes on the bases of morfological markers. Genetika, 50 (3), 895-906.

Stevanovic V., Vasic V (1995). Biodiveritet Jugoslavije sa pregledom vrsta od međunarodnog značaja. Ecolibri, Beograd, Biološki fakultet, Beograd.
Surlan-Momirović G., Katić S., Vasiljević S., Nikolić Z., Branković G., Ćalić I., Milić D., Mikić A. (2010). Use of genetic markers in breeding of perennial legumes. Rat. Povrt. / Field Veg. Crop Res., 47 (2), 417-424.

UPOV (1998): Guidelines for the Conduct of Tests for Distinctness, Uniformity and Stability of Soya Bean (Glycine max (L.) Merrill). UPOV, Geneva.

Vasiljević S., Lukić D., Katić S. (1999). Analiza prinosa i kvaliteta krme sorti crvene deteline. Zbornik radova 2. međunarodne naučne konferencije: Proizvodnja njüskih biljaka na pragu XXI veka. Univerzitet u Novom Sadu, Poljoprivredni fakultet, Novi Sad. 17-18 novembar, 22.

Vasiljevic S., Pataki I., Surlan-Momirovic G., Zivanovic T. (2005). Production potential and persisitence of red clover cultivars. EGF - Grassland Science in Europe, 10, 577-580.

Vasiljevic S., Mikic A., Mihailovic V., Katic S., Lugic Z., SurlanMomirovic G., Zivanovic T., Milic D., Pataki I. (2006). Characteristics of domestic cultivars of red clover (Trifolium pratense L.) according to UPOV protocol. Book of Absracts, Thind Symposium of the Section for Breeding Orvanisms of the Serbian Genetias Society and Forth ScientificReseanbs Symposium on breeding and seed production of the Serbian Association of Plant Breeders \&o SeedProduers, Zlatibor, 16-20. May 2006,97.

Vasiljević S., Mikić A., Katić S., Mihailović V., Mikić V., Ćupina B. (2007). Current status of the Trifolium pratense collection in Novi Sad, Serbia. Book of Abstracts of the 18th EUCARPIA Genetic Resources Section Meeting Plant Genetic Resources and Their Exploitation in the Plant Breeding for Food and Agriculture, Piešt'any, Slovakia, 2326 May 2007, 110-111.

Vasiljević S., Milić D., Mikić A. (2009). Chemical attributes and quality improvement of forage legumes. Biotechnology in Animal Husbandry, 25 (5-6), 493-504.

Vasiljević S., Katić S., Mihailović V. (2011). Oplemenjivanje crvene deteline (Trifolium pratense L) na poboljšan kvalitet krme. Zbornik. referata 45. Savetovanja agronoma, Zlatibor, 30.01-05.02.2011, 127137.

Vasiljević S., A. Mikić, V. Mihailović, S. Katić, D. Milić, Đ. Karagić, B. Milošević (2012). Characterization and utilization of red clover (Trifolium pratense L.) collection in Novi Sad. Book of Abstracts. I International Symposium and XVII Scientific Conference of Agronomists of Republic of Srpska. Trebinje, Bosnia and Herzegovina, March 19-22, 293.

Vasiljević S., Bursać M., Cvejić J., Mihailović V., Karagić Đ., Milić D., Milošević B., Katanski S. (2013a). Phytoestrogen content in serbian red clover cultivars. Proceeding of the International Scientific Conference "Biologically active substances of plants - studying and application", Minsk, 29-31 May 2013, vol. 8, iss. 2, 66-70.

Vasiljević S., Ćalić I., Salem Ahsyee R., Zorić M., Šurlan Momirović G., Karagić Đ., Živanović T. (2013b). Genetic diversity of red clover (Trifolium pratense L.) determined by phenotypic traits and SSR molecular markers. 30th Meeting of the EUCARPIA Fodder Crops and Amenity Grasses Section "Quantitative traits breeding for multifunctional grasslands and turf". Book of Abstracts, May 12-16, Vrnjačka Banja, Serbia, 26-27.

Vasiljević S., Radinović I., Vlaisavljević S., Mikulić M., Milošević B., Katanski S., Dolapčev A., Dragić V. (2019). Novi izazovi u oplemenjivanju crvene deteline (Trifolium pretense L.) u održivoj poljoprivredi. Zbornik apstrakata, XIV Simpozijum o krmnom bilju Srbije „Značaj i uloga krmnih biljaka u održivoj poljoprivredi Srbije”, 1819. april 2019, Poljoprivredni fakultet - Zemun, 21-22.

Vlaisavljevic S., Kaurinovic B., Popovic M., Djurendic-Brenesel M., Vasiljevic B., Cvetkovic D., Vasiljevic S. (2014). Trifolium pratense L. as a Potential Natural Antioxidant. Molecules, 19 (1), 713-725.

Vlaisavljevic S., Kaurinovic B., Popovic, Vasiljević S (2016). Profil of phenolic compaunds in Trifolium pratense L. extracts at different growth stages and their biological activities. International Journal of Food Properties, 1094-2912, http:// dx.doi.org/10.1080/10942912.2016.1273235

Weise S, Opermann M, Maggioni L, van Hintum T, Knupffer H. (2017). EURISCO. The European search catalogue for plant genetic resources. Nucleic Acids Research, 45, D1003-D1008. 


\section{Značaj genetskih resursa leguminoza za oplemenjivanje}

\section{Jegor Miladinović · Vojislav Mihailović · Vuk Đorđević · Sanja Vasiljević · Snežana Katanski · Dalibor Živanov · Predrag Ranđelović}

Sažetak: Cilj rada je bio da se prikažu biljni genetski resursi (BGR) kojima raspolaže Centar izuzetnih vrednosti za leguminoze Instituta za ratarstvo i povrtarstvo, Instituta od nacionalnog značaja za Republiku Srbiju. Genetski resursi leguminoza (soja, lucerka, crvena detelina, grašak i grahorice) predstavljaju dragocen polazni materijal i izvor raznovrsne genetske divergentnosti za stvaranje novih sorti prilagođenih određenim agroekološkim uslovima. Među leguminozama, soja zauzima najveće površine i spada u red najznačajnijih gajenih biljaka u svetu. Do sada postignuti i valorizovani rezultati istraživanja u zemlji i svetu potvrđuju lidersku poziciju u regionu i šire, a novosadsku genetiku soje čine prepoznatljivom. Kolekcija lucerke poseduje oko 800 genotipova različitih varijateta i nivoa dormantnosti. Kraj XX i početak XXI veka, karakteriše primena novog koncepta oplemenjivanja lucerke na prinos per se, koji treba da iskoristi prirodni heterozis u cilju stvaranja semihibrida. Centar izuzetnih vrednosti za leguminoze raspolaže sa 655 genotipova crvene deteline, oko 730 genotipova graška i 495 genotipova grahorica. Značajan doprinos nauci je stvaranje prve sorte ozimog graška za zrno u Jugoistočnoj Evropi (NS Mraz).

Ključne reči: centar izuzetnih vrednosti, genetska divergentnost, leguminoze, oplemenjivanje, resursi

This article is distributed under the terms of the Creative Commons Attribution 4.0 International License (http://creativecommons.org/licenses/by/4.0), which permits unrestricted use, distribution and reproduction in any medium, provided you give appropriate credit to the original author(s) and the source, provide a link to the Creative Commons license, and indicate if changes were made. 